\title{
The Power of Relationships: Love and Solidarity in a Landless Women's Organisation in Rural Bangladesh
}

\author{
Naila Kabeer and Lopita Huq
}

\begin{abstract}
This article examines the significance of social relationships in women's lives and their relevance to processes of women's empowerment. In Bangladesh, traditional structures limit women's social interaction to their immediate family and maintain male responsibility over them. However, here we look at the example of Saptagram - a social mobilisation organisation particularly focused against gender injustice towards rural landless Bangladeshi women - and how by providing relationships beyond the private sphere it engendered bonds of friendship and loyalty amongst its beneficiaries. Difficulties with systems and its inability to recruit a new line of leadership led to its apparent failure at one point. Yet, despite this, by providing knowledge of rights, respect, courage to stand up for one's beliefs and a sense of wellbeing through working alongside people in the villages, it inspired an enduring solidarity amongst the women it served which led to its eventual resurrection.
\end{abstract}

\author{
1 Introduction \\ This article explores the apparent loyalty of a \\ group of landless rural Bangladeshi women to a \\ social mobilisation organisation to which many \\ have belonged for over 20 years. This loyalty is of \\ particular interest because Saptagram, 'the \\ organisation in question, ran into problems in \\ around 1996 and virtually ground to a halt \\ between 1997 and 2001. It was widely assumed \\ that the organisation would disappear completely \\ with the death of its founder in 2000. Instead, \\ Saptagram resumed its work in 2001 albeit on a \\ much reduced scale. ${ }^{2}$ The story of Saptagram is \\ clearly not a story of organisational success. On \\ the contrary, by certain criteria, the organisation \\ would be deemed to have failed. We were \\ therefore interested in finding out why, despite \\ its troubled history, some of its older group \\ members had chosen to remain with the \\ organisation. To address this question, we drew \\ on the few studies available on the organisation \\ (Kabeer 1985; Arn and Lily 1992; Guttman 1993; \\ Howes 1999) as well as conducting a survey of \\ 114 of its older members and 100 new ones and \\ detailed interviews with 16 older members.
}

Our research uncovered a number of issues. These include familiar problems associated with 'charismatic leadership' within nongovernmental organisations (NGOs) as well as the sometimes positive, sometimes destructive influence of donors in shaping civil society. It also suggested that the organisation had had an enduring impact on its members' lives. Despite lower levels of education among older members compared with newer ones, they were more knowledgeable about their rights and local politics, more likely to demonstrate leadership skills and more likely to participate in local politics and engage in collective action. This article is not, however, concerned with a generalised analysis of the organisation and its impacts. Instead, it focuses on a different aspect of our findings, one that does not receive a great deal of attention in the mainstream development literature but that resonates with the themes of this IDS Bulletin. It relates to the significance of social relationships in women's lives and their relevance to processes of women's empowerment. 


\section{Women's empowerment and development organisations}

Studies of women in rural Bangladesh during the 1970s and 1980s were largely preoccupied with the resilience of the structures that constrained women's life choices (Cain et al. 1979; Islam 1979). They pointed out that families were organised around patriarchal relationships which placed women in a subordinate position to men, both within the family and in the wider community. Descent and property was transmitted through the male line, leaving women effectively property-less and genealogically irrelevant. The practice of female seclusion restricted their physical mobility to the domestic domain, curtailing their ability to participate in economic and political life. Marital practices cut women off from their own families' support, requiring them to reside with their husband's family after marriage, often in another village. These interacting patriarchal constraints not only limited women's access to resources, they also restricted their social relationships to those given by family, kinship and position within the community. Women remained under the guardianship of men all their lives, passing from the responsibility of father to husband to son.

Subsequent literature shifted the emphasis from structures to agency and to processes through which these structures could be transformed. This literature ranged from concerns with women's access to resources, such as microcredit, paid work and education, to more intangible changes in consciousness and identity. Given the social isolation of women in the South Asian context, their greater 'embeddedness' relative to men in family and kinship relations, feminist literature placed particular emphasis on the importance of expanding women's social relationships, building their solidarity with other women and strengthening their capacity for collective action in pursuit of gender justice (Kabeer 1985, 1994; Batliwala 1993; Agarwal 1994). An important dimension of this process of social change is the expansion of relationships in women's lives beyond the 'given' relations of family and kinship within which they occupy a subordinate position to relationships which they have chosen and which expand the knowledge they can draw on and their capacity for agency.

Civil society organisations (CSOs) that seek to engage directly with women clearly hold potential for making such transitions possible. In the context of rural Bangladesh, development NGOs are the most likely candidates by virtue of their prominence in rural areas and their focus on organising women into groups. However, as research from the wider South Asian context shows, development NGOs have had widely varying outcomes (Kabeer 2005; Holvoet 2005). It suggests that group formation on its own does not necessarily bring about the changes associated with women's empowerment. Rather, it is the group formation strategies pursued by different organisations, their understanding of the causes of gender inequality and their commitment to bringing about social change that makes the difference.

The analysis of efforts to bring about women's empowerment has rarely gone beyond the 'given' relationships in women's lives. The quantitative strands of this research have focused on a fairly narrow set of the measurable changes, with women's roles in household decision-making and their mobility in the public domain appearing most frequently. The more qualitative literature has teased out some of the changes in women's sense of identity and self-worth as well as shifts in power relationships within the family. Neither body of research has paid much attention to the impact of group membership on women's wider social relationships and the implications of this for their capacity to bring about social change. Yet, there is some evidence to suggest that organisational strategies have implications for both the range and quality of relationships in women's lives (Mahmud 1999; Kabeer 2009). The significance of social relationships in processes of empowerment ${ }^{3}$ was also noted in an early study of Saptagram, by Naila Kabeer (one of the authors of this article):

Perhaps the most important achievement of the women's groups is that of breaking down traditional forms of alliances that are based on a patron-client relationship between the wealthy, matabbar families and the poor and landless classes. Traditionally both women and men give their labour and loyalty to their patrons in return for work and protection. The exploitative nature of such relationships is never explicit because it is disguised in terms of patronage or kinship. The groups provide the women with a form of organisation that they can choose to belong to (unlike those 
based on family, kinship or patronage where their consent is not required) and that requires them to define and fight for their interests and those of their families, instead of having to accept socially determined priorities. This is an important break with the past for them. (Kabeer 1985: 209 [italics and brackets added])

However, the study in question was based on secondary observations during fieldwork carried out in 1980 into a very different set of issues. It could therefore provide little insight into the substance of this 'break with the past'. Interviews carried out with Saptagram group members nearly three decades later offer the opportunity to explore the substance of this break in greater detail.

\section{A brief history of Saptagram}

Saptagram was set up in Faridpur district in 1976 by Rokeya Rahman Kabeer ${ }^{4}$ (RRK) as an organisation to be run for women by women. This was unique at a time when the development NGOs in existence were all led by men and focused primarily on problems of class and poverty. This was also a time when the NGO presence was far less pervasive in the villages of Bangladesh than it is today. An evaluation study in the early 1990s noted that Saptagram was generally the first NGO to move into the areas in which it was working (Arn and Lily 1992: 18).

Saptagram defined itself from the beginning in feminist terms, albeit with a class perspective. Its core mission was the empowerment of rural women through a social movement against gender injustice that prioritised, but was not limited to, landless women. It organised women into groups of varying sizes and provided popular education and legal training classes in order to promote their capacity to analyse, question and act on the structures of gender injustice in their lives. In response to requests from its group members, Saptagram also began organising men's groups but its male membership never exceeded 10 per cent of the total. The organisation had a range of secondary activities, which were intended to support its core programme (Kabeer 1985; Howes 1999). These activities were based on the fundamental belief that without some degree of economic security, poor rural women could not be expected to take action against the injustices in their lives.
However, it rejected the microcredit model that was beginning to emerge in Bangladesh at the time of its inception and opted instead for a savings-led model that would build the collective economic capabilities of its membership.

The savings programme provided the basic rationale for the women to come together as groups and meet on a weekly basis. The idea of saving was not new to rural women - they had a long-standing tradition of keeping aside a fistful of rice on a daily basis to save for a rainy day but the idea of collective saving was. Women saved on a regular weekly basis and decided how they would use the money. These funds were initially kept by the women members, but later put into joint bank accounts. Saptagram provided loans for collective enterprises to its group members. In addition, it provided training in various livelihood skills and social development and linked its members to local government officials and service providers.

Saptagram was unusual at the time in the fact that the majority of its staff was female ${ }^{5}$ - young women recruited from the districts in which Saptagram worked. Most were married and had children, belying the widespread assertion in Bangladesh that married women were not prepared to take up full-time fieldwork. It also had a much lower turnover of staff than other NGOs where women rarely stayed for more than a year (Arn and Lily 1992). The explanation, according to this study, was straightforward: 'Saptagram has created working and living conditions to suit the requirements of female field staff instead of demanding that the women adjust and try to behave and work as men, as quite a number of other organisations do' (1992: 57).

The overall vision and direction was largely driven by RRK who remained its executive director from its inception in 1976 until her death in 2000. She fitted into the 'charismatic' model of leadership discussed in the NGO literature (see for instance, Gamble 2005). Her personal qualities, her capacity for immense warmth towards her staff and group members, provided a great deal of the inspiration and vibrancy of the organisation in the early years. Both staff and group members addressed her as khalamma, an affectionate way of addressing an aunt. But she was also seen as a formidable person to deal with by those in authority, able to 
draw on both her own personal authority and her extensive networks to deal with obstacles. As one of her staff members told us:

\section{Wherever khalamma went, whether to the police} station or the courts, everyone used to be scared of her. Because of her, they would also fear Saptagram workers.

In a country where women were still largely hidden from public view, she provided a visible and dramatic role model.

RRK made periodic efforts to recruit her replacement among younger women. This was a difficult but not impossible task. A number of women who fulfilled the criteria for the position joined the organisation as Project Directors and did what they could to put systems in place. But the failure to build a second line of leadership to take over the directorship was widely attributed to the force of her personality. The personal qualities that made RRK an effective force in tackling the weight of patriarchal traditions thus proved to be a liability when it came to nurturing this second line of leadership. She was also strongly influenced by the jealousies of some of the longer standing field-based staff - those she viewed as the 'real' Saptagram - towards the educated, middle-class women recruited into potential leadership positions. Consequently, the organisation continued to be characterised by 'a charismatic leadership, short channels of decision-making and flexible decision-making' (Howes 1999: 8).

\section{The decline of Saptagram}

The implications of this failure to establish proper systems became evident as the organisation came under pressure to expand. Until the 1990s, Saptagram, like most of the more radical NGOs of that period, relied on small grants from international NGOs such as Oxfam, as well as progressive bilateral donors such as the Swedish International Development Cooperation Agency (SIDA) and Norwegian Agency for Development Cooperation (NORAD). By the early 1990s, the rise of neoliberal ideologies within the international donor community had led to a growing focus on NGOs as a preferred alternative to the state in the delivery of services. There was a massive expansion in official aid flows to NGOs in Bangladesh, along with calls for them to scale up their operations and move towards financial sustainability (Devine 2003). A version of these changes played out in the microcosm in Saptagram.

Guttman (1993) notes the scale of funding that Saptagram had been accustomed to dealing with: a grant of US\$50,000 over three years from 1990 from Oxfam; US\$60,000 from NORAD in 1992 and a grant of US\$50,000 for two years from SIDA. This changed in the next grant round when a number of its donors came together to scale-up their support, a response to extremely positive evaluations of the organisation (Guttman 1993). A budget of nearly $\$ 3$ million was agreed for the three-year period, 1993-6, with Saptagram expected to raise $\$ 1$ million from its own economic activities. This was a massive increase of funding to a small organisation, particularly one that continued to be run, according to its then Project Director, with the informality of a voluntary organisation (Tahera Yasmin, cited in Guttman 1993).

A member of NORAD staff highlighted the problems in our interview with her. She pointed to the existence of a serious information gap between the head office in Dhaka and field operations because of the absence of effective monitoring systems. In addition, she observed that the organisation was being asked to generate funding for its own operations when it did not have a great deal of technical or financial know-how or any idea about business planning:

These systems were simply not mature enough ... The problem was that too many resources had already been poured in. Where we should have invested $\$ 100$, we invested $\$ 500 \ldots$ when this happens, opportunities for the misuse of funds become inevitable.

A management review commissioned by donors in 1996 found evidence of major mismanagement, lax financial procedures, and accusations of nepotism and favouritism. Subsequent efforts to streamline the organisation were already too late. Divisions between the staff had become highly visible and openly conflictual. The donors withdrew and the NGO Affairs Bureau froze Saptagram's funds until it could carry out its own audit. The director's health had been failing for some time and she died in 2000. As noted earlier, it was widely assumed that the organisation would die with her. 
The discovery that Saptagram had resumed activities, albeit on a much reduced scale, therefore came as a surprise to those who had known the organisation's history. Some of its older staff had managed to persuade the NGO Affairs Bureau that they were capable of managing the organisation's affairs and had revived group membership in the older zone of Saptagram's operations. This suggested that, almost unbeknownst to itself, Saptagram had succeeded in building a second line of leadership capable of taking charge. Their success was all the more surprising in view of the fact that there were now many more NGOs working in the areas in which Saptagram had been active.

It was to investigate this phenomenon that we decided to include Saptagram in a larger study we were carrying out on the links between development NGO strategies and outcomes. ${ }^{6} \mathrm{We}$ believed that understanding of what had led a group of landless women to remain loyal to an organisation through its troubled years, including a period of closure, would provide important insights into what they valued about the organisation's vision, strategies and the changes it allowed them to achieve. This assumption was borne out by our research. The women we interviewed spoke at length about what the organisation had done for them. This included many of the impacts that are standard in the NGO literature: economic improvements in women's lives and changes in knowledge, attitudes and practices relating to health, family planning, sanitation and education. However, these were not the changes that were most prominent in their accounts. Instead, it was the more intangible gains that appeared to have the more enduring value and that they spoke of at greatest length.

\section{Consciousness and capabilities: 'we were in a dark room with our eyes closed'}

Transforming women's consciousness and capabilities was one of the core elements of Saptagram's strategy for social change. It relied on group discussions, training, cultural activities and exposure visits as the means to achieve this change. The courses it developed went well beyond basic literacy and livelihood skills to address its central concerns with gender and class injustice. It had originally used courses developed by other development NGOs but found them to contain too many gender stereotypes to serve its own view of social change. Over time, it developed its own course curriculum, which sought to bring a strong gender perspective to the analysis of class and poverty.

Interviews with Saptagram members suggested that knowledge gained through these courses was transformative in its impact: it transformed how they saw themselves, expanded their horizons, altered their behaviour and strengthened their ability to interact with others around them, including those who they had previously feared. Hamida believed that she had learnt to value her own contributions to her family's wellbeing and to demand respect for it from others:

We were not given any respect by men, no matter how much work we did around the house... Husbands would come, eat the meals we cooked and then go out again. If there was any change from the norm, there would be abuse and violence. Now I learnt about our rights. You come home after working outside, I have also been working at home all day. I took the cow out, gave it food, I cleaned the house, cooked, washed the dishes. This is not easy work. I was not just sitting around. On what basis, can you get angry with me?

Kohinoor talked about the arbitration skills she had learnt and the courage she had acquired to stand up for her beliefs:
We learnt how to do arbitration in disputes. If a husband is beating the daylights out of his wife, five of us women go there and warn him not to make trouble. Because we took this training for arbitration, we are able to talk like this. I could not have done this earlier; I did not have the courage to talk to people then... Earlier if I saw a group of people are sitting together, I did not have the courage to go up to them and say anything. Now even if there are 100 people sitting together, I can go up to them and have my say. Earlier, if we saw a policeman on the road, we would run. Now even if we go to court, we can talk to policemen there. We have achieved this much power.

For Rashida, knowledge of her rights was the lesson that she most valued:
I have learnt how to stand on my own two feet from Saptagram, the value of unity, how to overcome problems, how to mix with people, how to sign my name. And I have learnt about our rights. Now I understand that I have the same rights as my 
husband. I didn't get rights earlier and I cannot say that I get them all even now. But at least I now know what they are and I can teach my children. If I didn't know that we have a right to my father's property then I wouldn't have been able to get it from my brothers. This is also a right... Whether I get my rights or not, I can still demand them.

The transformative nature of what they learnt from Saptagram, its impact on all aspects of their lives, was summarised particularly succinctly by two of the women we spoke to:

\section{I was an idiot before I joined Saptagram. I didn't} know anything about the world... (Safia)

We were in a dark room with our eyes closed. Saptagram came and opened our eyes. It gave us strength. (Rabeya)

\section{Solidarity and social relationships: 'the tree of Saptagram'}

The other core element of Saptagram's strategy revolved around building relationships based on solidarity and mutual support among groups of women with shared experiences of class and gender oppression. Along with values embedded in all its training programmes, it promoted group-based savings programmes, joint economic enterprises, regular meetings and discussions and various forms of collective action from the annual celebration of International Women's Day to demonstrations against incidents of injustice.

One striking point that emerged from their accounts was the level of hostility from the community that older members encountered when they joined the organisation. Their relationships with each other had been forged in the face of this resistance and cemented by their struggle for the right to belong. Rashida believed that it was the values that the organisation had taught its members and the support it provided them that gave them the strength to stay united in the face of the community hostility:

No other NGOs have taught us the way that Saptagram did nor did we get it anywhere else in the community. Instead people of this area created obstacles - they wanted to break our legs, they wanted to crack our heads open, ostracise us from the society. They said they wouldn't come to our children's wedding. They used to swear at us using bad language. We overcame all the obstacles and we had the strength so long as the organisation was with us. Now we are with them, though we had swerved in the middle.

Tamanna emphasised both unity and numbers as the factors that had allowed group members to deal with community resistance:

There were so many barriers in those days and so much loose talk. Many religious people came to stop us.

They said things like, 'Wives and daughters can't go to the field, crops don't grow if women go to the field'. But how many of them are there? We have the numbers. How did Khaleda Zia and Begum Hasina become rulers of this country? Through us. So who do the matabbars now come to for their power? To us, right? Without our support, how can they have power?

Saptagram's willingness to work with men, to form men's groups where there was a demand, appeared to have paid off in terms of the solidarity offered to the group members by men within their families. Jyotsna said that she was able to go her own way, despite continued comments about her boldness, because she had her husband's backing:

Earlier, neighbours would say, 'Look at this woman, she goes here and there on her own, she goes to meetings'. They still say it, but I don't listen to anyone. Even now they ask why I have meetings every day. I say that if I have a meeting I will surely go. No one can stop me. My husband defends me. He says that she is not going for any wrong reasons, she knows the difference between what is good and bad.

Shathi related the occasion when she and her group members had stood up to a fundamentalist preacher in a public meeting and the importance of the support they had received from the men in her village:

Once a mullah came to our village to preach. He said that Bangladesh has been destroyed because of women, that there is more corruption because of women, that poverty has increased because of women, that if women walk across a field it catches on fire... When he started talking about women, a number of us women got together. We confronted the mullah and asked him whether he was not borne by a woman. And does everything happen because of women and nothing because of men? One of our brothers caught me and clapped my mouth shut and sent us home telling us that he won't talk anymore about women. We did go 
home, but our husbands who had now become aware stood up and warned the mullah not to speak that way about women. They said, the world cannot exist without women. Were you not borne by a woman? They created trouble and stopped the man from preaching. This happened because of our group. If I were alone, this would not have been possible.

A number of women spoke of the difference that these relationships of solidarity had made at both personal and social levels. For Shathi, it overcame her sense of being alone:

\section{If I face a problem, then five of us can together solve that problem. Before when I used to go to work in different places, I was alone: I worked, I earned my money and I came home. Here, we are united.}

Jamuna credited their group unity with greater awareness on the part of women and a reduction in domestic violence:

Women are not as foolish as they used to be. Now everyone realises their own rights. We didn't know this earlier. By going for processions, by getting together, becoming united, by becoming members, we have learnt. When we were by ourselves, there was no unity. Now everyone is together. There are 20 members here; can anyone's husband come here to beat her?

Nor was this solidarity confined to group members. Both Jyotsna and Rashida described how they used their collective clout to ensure a fairer distribution of government services:

If someone needed help, we would give them from our funds to help them. Maybe someone can't take their child to the doctor... We go to the shalish and we would speak out if the judgement was not right. We once went to the Member because our neighbour did not have a proper latrine. Two or three of us from the group went to speak to the Member on her behalf. That didn't work. But when we gave a written petition, we wrote that we were Saptagram members, it worked. We learnt through training that unsanitary latrines are bad for us. There were a number of such latrines here then, we had sanitary ones installed.

We go to the Social Welfare office, to the TNO office to find out when the VGD/VGF cards, old age pension cards are going to be distributed. We have been made aware where our rights lie. We go to the members to find out how we can get sanitary latrine. We keep in touch with the chairman/member to show where the tube-well should be located so that most people benefit from it. It is through the NGOs that we became acquainted with the chairman/member. We know where the blind and the deaf can get an education, where we can get disability stipend. We know what to do if there is an acid attack. Now we know where we can get justice.

The flourishing of 'chosen' relationships in these women's lives also encompassed their relationships with the staff of Saptagram. Obviously, the material gains they had made through their membership of the organisation played an important part in their feelings towards the organisation. But their loyalty was also based on the affection, for women who had come into their lives before any other development organisation, who had lived among them over the years and who had offered them an unconditional form of support that was very different from the benefits on offer from most NGOs today. Jamuna told us:

Saptagram came here first. We were a part of its groups. Then the useless organisations came. But when we loved someone first, is it possible to love someone else later? People love the one who comes first. Their office was close to our homes, the office apas would come and talk to the people in the village, they did a lot for the people in this village. They would come and husk paddy with my aunts.

Golapi pointed to a tree in her homestead, 'After the 1988 floods, Saptagram distributed saplings for us to plant: guavas and amra. This jackfruit tree is a symbol of Saptagram for me: it bears wonderful fruit'.

Hamida recalled Saptagram's past in words that captured the deep sense of wellbeing that the organisation had given to those whose lives it had touched:

If there was a programme at that time, there would be so many people, the Saptagram field would get filled with men and women. People used to feel the same kind of peace there that they felt during Eid prayers.

\section{Conclusions}

There were many reasons why women opted to stay with Saptagram, in spite of the problems that had beset it. There were important material reasons. While the women we spoke to were by no means affluent, they had achieved a degree of 
economic security that had helped to diminish their reliance on patronage relationships. They had learnt about their environment, about family planning and ensuring the health of their children. However, these changes on their own could not account for the courage that these women displayed in challenging injustices within their families and in the wider community. More important was the organisation's ability to carve out a social space in which new kinds of chosen identities and relationships had been able to flourish. The bonds of friendship and solidarity between group members had been forged and strengthened through many years of dealing with adversity together. It was the power of these social relationships that they drew on in confronting relationships of power within their community.

For all its failings and limitations, there was clearly something about the way that Saptagram worked that set it apart from other NGOs in Bangladesh. The overwhelming majority of NGOs in Bangladesh work with women and organise women into groups. To that extent, they all provide the possibility of expanding the range of 'chosen' relationships in women's lives. But the substance and quality of the relationships

\section{Notes}

* The interviews with the Saptagram members were conducted by Mr Saiful Islam and Mr Mahbub Ul Alam. The interviews with Saptagram staff were conducted by Kabita Chowdhury and Lopita Huq. Many thanks to Rajni Palriwala for comments on an early draft.

1 The full name of the organisation is Saptagram Nari Swanirvar Parishad or the Seven Village Women's Self-reliance Organisation, so called because the original intention had been to work in the seven villages that separated the founder's own village in Faridpur district from the village of her husband. In fact, it later covered a large number of villages in a number of districts.

2 From over 25,000 group members in its more active period, the organisation now has about these organisations build vary considerably according to their vision, values and strategies. The provision of microfinance has been found to create a business relationship but little beyond that. Social mobilisation organisations create a more enduring set of relationships, a sense of loyalty and solidarity of the kind we have noted in this article.

However, in the course of our research into development NGOs in Bangladesh, it is only in the case of Saptagram that group members spoke of their love for an organisation based on a sense of personal ownership. Saptagram had offered them the possibility of relationships that they could choose to belong to at a time when the only relationships open to them were ascribed by society. It had taught them to value themselves as equal human beings when others around them expected them to accept their inferior position in unquestioning silence. And it had given them unconditional support in their efforts to better the lives of women when most of the organisations that came later offered only microcredit. The enduring difference that it had made to their lives explains their continued loyalty to the organisation today.

2,000 members. Around 700 of its older members have rejoined the organisation; the rest are new.

3 Although a re-reading of this article for the present article revealed that, while it covers some of the same ground covered in the present article, the word 'empowerment' does not appear in it.

4 Rokeya Rahman Kabeer was the mother of Naila Kabeer.

5 Out of 140 employed in 1993 (Howes 1999).

6 The larger study of eight NGOs in Bangladesh is part of the Development Research Centre, led by the Institute of Development Studies and funded by DFID. The Bangladesh component of the research is carried out in collaboration with BRAC Development Institute, Dhaka. 


\section{References}

Agarwal, B. (1994) A Field of One's Own. Gender and Land Rights in South Asia, Cambridge: Cambridge University Press

Arn, A-L. and Lily, F. (1992) Evaluation Report of Saptagram Nari Swanirvar Parishad, Oxford: Oxfam

Batliwala, S. (1993) Empowerment of Women in South Asia: Concepts and Practices, New Delhi: Food and Agriculture Organization - Freedom From Hunger Campaign/Action for Development (FAO-FFHC/AD)

Cain, M.; Khanam, S. and Nahar, S. (1979) 'Class, Patriarchy and Women's Work in Bangladesh', Population and Development Review 5.3: $405-38$

Devine, J. (2003) 'The Paradox of Sustainability: Reflections on NGOs in Bangladesh', Annals of American Academy of Political and Social Science, November 590: 227-42

Gamble, J. (2005) 'Thought and Action. Perspectives on Leadership and Organisational Change in the Indian Voluntary Sector', mimeo, Montreal: McGill University

Guttman, G. (1993) 'In our own Hands', Education for All Innovation Series, No 2, Paris: UNESCO

Holvoet, N. (2005) 'The Impact of Microfinance on Decision-making Agency: Evidence from South India', Development and Change 36.1: 75-102
Howes, M. (1999) NGOs and the Development of Membership Organisations: The Case of Saptagram, IDS Discussion Paper 370, Brighton: IDS

Islam, M. (1979) 'Social Norms and Institutions', in Women for Women (ed.), The Situation of Women in Bangladesh, Dhaka: Women for Women

Kabeer, N. (2009) Citizenship Narratives in the Absence of Good Governance: Voices of the Working Poor in Bangladesh, IDS Working Paper 331, Brighton: IDS

Kabeer, N. (2005) 'No Magic Bullets: Gender, Microfinance and Women's Empowerment in South Asia', Economic and Political Weekly XL.44 and 45: 4709-18

Kabeer, N. (1994) Reversed Realities. Gender Hierarchies in Development Thought, London: Verso

Kabeer, N. (1985) 'Organising Landless Women in Bangladesh', Community Development Journal 20.3: 203-11

Mahmud, S. (1999) 'Informal Women's Groups in Rural Bangladesh: Group Operation and Outcomes', paper presented at Workshop on Group Behaviour and Development at the World Institute for Development Economics Research, Helsinki, 10-11 September 